\title{
Safety, immunogenicity and efficacy of influenza vaccine in children
}

\begin{abstract}
Otávio A. L. Cintra, ${ }^{1}$ Luis C. Rey ${ }^{2}$
Abstract

Objectives: To review the immunogenicity, safety and efficacy of inactivated and attenuated trivalent influenza vaccines in children.

Sources of data: Database search of the medical literature indexed on MEDLINE, LILACS and in the Cochrane Library. Review articles, clinical trials and epidemiological studies published from 1990 to 2006 were selected for analysis.

Summary of the findings: Influenza is an infectious disease that is both universal and seasonal, with incidence in all age groups and annual epidemics characterized by excessive morbidity and mortality. The elderly and people with comorbidity are high risk groups for severe influenza. It has recently been proven that healthy infants suffer similar morbidity to other risk groups, and therefore vaccination against influenza is indicated for them too, as being the most effective means of preventing infection by the influenza virus. The safety of influenza vaccines in children appears adequate, with the most often observed adverse effects being local reactions or fever. Immunogenicity in children varies from 30 to $90 \%$, being directly proportional to age. Efficacy depends on the primary objective and can range from levels comparable with placebo to up to $91 \%$ efficacy against confirmed influenza $A$ infection. Schoolchildren play an important role in the dissemination of the influenza virus, and population studies have demonstrated herd immunity.

Conclusions: Trivalent influenza vaccines, whether inactivated or attenuated, have low reactogenicity and offer variable immunogenicity and efficacy in children. Vaccination is effective for prevention of infections by the influenza virus and for reducing morbidity. More powerful studies of efficacy and safety in infants are still required.
\end{abstract}

J Pediatr (Rio J). 2006;82(3 Suppl):S83-90: Influenza, vaccine, children.

\section{Introduction}

The influenza virus is the etiologic agent of the flu, causing annual epidemics which are associated with excessive hospitalizations and mortality, particularly among the elderly and those suffering from underlying conditions, such as cardiopulmonary and metabolic diseases and immunodeficiencies. ${ }^{1}$ Prevention of infection by the influenza virus by means of vaccination is recommended for all of these populations and their contacts and also anyone who does not wish to catch the flu. ${ }^{2}$

Recently, the Advisory Committee on Immunization Practices (ACIP), in the USA, ${ }^{2}$ and the American Academy

1. Infectologista pediátrico, Doutor em pediatria, Médico assistente, Departamento de Pediatria, Hospital das Clínicas da Faculdade de Medicina de Ribeirão Preto, Universidade de São Paulo (USP), Ribeirão Preto, SP, Brasil. Docente, Faculdade de Medicina Barão de Mauá, Ribeirão Preto, SP, Brasil.

2. Pediatra infectologista, Doutor, Unidade de Pesquisas Clínicas, Hospital Universitário Walter Cantídio, Universidade Federal do Ceará (UFCE), Fortaleza, CE, Brasil. Mestre, Universidade Estadual do Ceará (UECE), Fortaleza, CE, Brasil.

Suggested citation: Cintra OA, Rey LC. Safety, immunogenicity and efficacy of influenza vaccine in children. J Pediatr (Rio J). 2006;82(3 Suppl):S83-90 of Pediatrics 3,4 recommended routine influenza vaccination for children aged 6 to 23 months, considering this age group to be at high risk of increased severity of infection by the influenza virus. This recommendation was based on epidemiological surveys that demonstrated that children in this age group exhibit hospitalization rates that are greater than or equal to those observed in other high risk groups. ${ }^{5,6}$ Furthermore, use of the inactivated influenza vaccine with children at this age has been proven to be safe and to have acceptable efficacy, backing up the recommendation. 7,8 The Infectology Department of the Brazilian Society of Pediatrics also recommended the inclusion of influenza vaccination for children from 6 to 23 months in the vaccination schedule they presented at the XIV Brazilian Congress of Pediatric Infectology, held at Foz do Iguaçu (state of Paraná, Brazil) in April 2005. In the light of this recommendation, in conjunction with other significant epidemiological data on the role of children in the transmission, morbidity and mortality of influenza epidemics, it is considered appropriate to discuss the subject. 
The objective of this review is to use medical literature and Brazilian epidemiological data to briefly characterize the impact of the flu and the benefits, immunogenicity, safety and efficacy of vaccinating healthy children against the influenza virus, especially in the 6 to 23 months age group.

Database searches were run on MEDLINE, LILACS and the Cochrane Library and specialists were consulted on the following themes: influenza, influenza vaccine, infants, vaccine efficacy and adverse events. The most relevant articles were selected from those that reported on randomized, double-blind and controlled clinical trials, in addition to national or international epidemiological population-based incidence studies.

\section{Biology and epidemiology of the influenza virus}

The influenza virus is an orthomyxovirus with an envelope and single-strand segmented RNA. It has two surface glycoproteins, which play important roles in its antigenicity and pathogenicity, named hemagglutinin (HA) and neuraminidase (NA). ${ }^{9}$ Influenza viruses are classified into one of three subtypes, A, B or C, with the first of these being associated with the greatest antigenic variation in $\mathrm{HA}$ and $\mathrm{NA} .{ }^{9}$ Three $\mathrm{HA}(\mathrm{H} 1, \mathrm{H} 2$ and $\mathrm{H} 3$ ) and two NA (N1 and N2) variants are associated with infections in human beings, ${ }^{9}$ although other variants, such as $\mathrm{H} 5 \mathrm{~N} 1$, that are typically observed in other species, have caused infections in humans who have had contact with poultry. 10,11

Influenza viruses cause annual epidemics that are associated with significant morbidity and mortality and have a major impact on public health, with around 20 thousand deaths/year and 140 thousand hospitalizations/ year, on average, in the USA. ${ }^{12,13}$ The populations at greatest risk present more severe infections by the influenza virus and excessive levels of pneumonia, mortality and hospital admissions, particularly among the elderly, cardiopulmonary patients and people with immunodeficiencies. ${ }^{12,13}$

In temperate countries and in the South and Southeast of Brazil, influenza virus epidemics typically occur during the winter months. ${ }^{14,15}$ In regions with tropical climates, however, they can happen at any time of year, sometimes more than once a year, and may be associated with rainy seasons. ${ }^{16}$ The circulation of the influenza virus is global and annual epidemics and pandemics are associated with population immunity to the subtype in circulation, with the epidemics being associated with small variations within a subtype (antigenic drift) and pandemics with major antigenic variation (antigenic shift). ${ }^{1}$

\section{Impact of the influenza virus on children}

Glezen et al. ${ }^{17}$ described the typical progression of an influenza epidemic, with an average duration of 6 to 8 weeks, starting among schoolchildren and later passing to economically active adults. The role of children in the spread of these viruses is clear, having also been reported in more recent epidemiological studies. ${ }^{18-21}$

Children do not only disseminate the influenza virus, but can also present significant morbidity associated with flu infections, with less typical and sometimes more severe clinical manifestations. ${ }^{22}$ Encephalitis cases caused by the influenza virus have been described in children. 23,24 In the USA, 121 deaths were associated with influenza infections in patients less than 18 years old, with just $26 \%$ of these having risk factors for greater severity. 25,26

The fact that hospital admissions among children under 5 years of age increase in frequency during influenza epidemics has been known for several years.27,28 Nevertheless, since the respiratory syncytial virus (RSV) is one of the principal agents of hospitalization in children less than 1 year old with lower respiratory tract infections, and since RSV exhibits similar seasonality to the influenza virus, the real importance of the influenza virus was initially undervalued in this age group. 28,29 Later, Neuzil et al. ${ }^{5}$ and Izurieta et al. ${ }^{6}$ demonstrated that the influenza virus was also associated with hospitalizations and morbidity to as significant an extent as RSV. These authors were able to characterize the varying periods of predominance of each agent and the rates of hospitalization associated with each one. Since then other studies have confirmed these authors' findings, demonstrating the true impact of influenza virus infections in children, associated with increased severity, increase in the number of medical consultations, use of antibiotics, parents' absenteeism from work and the appearance of secondary cases. ${ }^{19-21,30}$

Acute respiratory infections are the most important cause of mortality in children under 5 years in developing countries. ${ }^{31}$ Despite bacterial etiology being considered more associated with mortality, viruses present very significant frequency and are associated with secondary infections. ${ }^{16,32} \mathrm{Kim}$ et al. ${ }^{33}$ demonstrated an association between influenza epidemics and an increased number of identifications of pneumococcus in invasive infections, which was confirmed experimentally by Peltola et al. ${ }^{34}$ and by O'Brien et al. ${ }^{35}$ in case control studies of pneumococcal pneumonia. The experimental efficacy of vaccination and of treating influenza with antivirals for preventing mortality in mice by invasive pneumococcal infection were also recently confirmed. 36,37

\section{The impact of the influenza virus on children in Brazil}

Currently, the epidemiology of the influenza virus is well known in Brazil and its seasonality has been well characterized, with outbreaks taking place in the winter months in the South and Southeast regions. ${ }^{1}$ Brazil has referral centers for the diagnosis and identification of 
influenza viruses and is an active participant in the World Health Organization (WHO) influenza surveillance network, contributing with data to support the decision on the annual composition of the influenza vaccine to be used in the Southern Hemisphere. ${ }^{1}$ The morbidity of influenza virus infections in Brazilian children has not been analyzed systematically; however, there are several different published studies in which the influenza virus appears as a cause of acute respiratory infections and hospital admissions. 15,38-46

In the Ribeirão Preto area (São Paulo state), an increase was observed in the number of hospitalizations due to pneumonia and bronchiolitis in children under 5 years of age during the months that correspond to the greatest incidence of RSV and the influenza virus. ${ }^{15,38}$ During an influenza outbreak in 2004, the virus was detected in $13 \%$ of children under 1 year old admitted to hospital for bronchiolitis or pneumonia, ${ }^{39}$ in addition to concomitant occurrence with severe pneumococcal pneumonia. ${ }^{40}$ Paiva et al. ${ }^{14}$ studied an influenza outbreak in Iporanga (São Paulo state) and observed that $84.3 \%$ of cases were in children and adolescents up to 19 years of age. Moura et al. ${ }^{41}$ detected the influenza virus in $22.3 \%$ of children under 5 years old seen at emergency and/or health centers in Salvador (Bahia state). In the same city, a longitudinal follow-up study of children seen at day care who had presented respiratory symptoms detected the influenza virus in $7 \%$ of cases. ${ }^{42}$ In Rio de Janeiro (Rio de Janeiro state), Sutmoller et al. ${ }^{43}$ and Nascimento et al. ${ }^{44}$ detected the influenza virus in 10 and $6.7 \%$ of children under 5 years old with acute respiratory infections (ARI), respectively. In Porto Alegre (Rio Grande do Sul state), Stralioto et al. ${ }^{45}$ detected the virus in $1.7 \%$ of children from 0 to 5 years old with ARI seen at an emergency room. In a longitudinal study of children with respiratory symptoms in the city of Fortaleza (Ceará state) Arruda et al. ${ }^{46}$ detected the influenza virus in $5.7 \%$ of patients with upper airway infections.

Even without the mass of epidemiological data available on North-America, we can infer that the influenza virus is an important causal agent of ARI in Brazilian children under 5 years old and that it is associated with increased hospital admissions for lower airway infections, with significant morbidity.

\section{Influenza vaccines}

The different types of influenza vaccines are listed in Table 1 with their main characteristics, indications and course of doses. The vaccine presentations available in Brazil are listed in Table 2.

Inactivated vaccines are the primary means of preventing influenza infection, due to the vast experience of their use worldwide. ${ }^{1}$ Vaccines made with whole viruses exhibit good levels of immunogenicity, but have greater reactogenicity too, in particular causing fever in children and, therefore, are not indicated for this age group. ${ }^{1}$ Split vaccines, whether from fragmented or subunit viruses, offer a good safety profile, with the first being more immunogenic than the second and both being indicated for children under 12 years. ${ }^{8}$

Virosome vaccines are inactivated vaccines in which the HA and NA influenza virus surface antigens are incorporated into virosome (virus-like) particles that have an adjuvant role. ${ }^{47}$ This type of vaccine offers similar

Table 1 - Influenza vaccines

\begin{tabular}{|c|c|c|c|c|c|}
\hline Vaccine & Type of virus & Composition & Indications & Course/Route & Doses \\
\hline Whole viruses & Inactivated & $\begin{array}{c}\text { Whole inactivated } \\
\text { viruses }\end{array}$ & Over 12 years & 1 dose IM & $0.5 \mathrm{~mL}$ \\
\hline Split & Inactivated & $\begin{array}{c}\text { Split viruses } \\
\text { (HA, NA and capsule) }\end{array}$ & From 6 months & $\begin{array}{c}1 \text { or } 2 \\
\text { IM doses } *\end{array}$ & $\begin{array}{c}0.25 \mathrm{~mL} \\
\text { (6 to } 36 \text { months) } \\
0.5 \mathrm{~mL} \text { (> } 3 \text { years) }\end{array}$ \\
\hline Subunit & Inactivated & $\begin{array}{l}\mathrm{HA} \text { and NA } \\
\text { in isolation }\end{array}$ & From 6 months & 1 or 2 doses & - \\
\hline Virosome & Inactivated & $\begin{array}{c}\text { HA and NA } \\
\text { absorbed into } \\
\text { virosome particles }\end{array}$ & From 6 months & 1 IM dose & $\begin{array}{c}0.25 \mathrm{~mL}(6 \text { to } 36 \mathrm{~m}) \\
0.5 \mathrm{~mL} \text { (> } 3 \text { years) }\end{array}$ \\
\hline Cold-adapted & Attenuated & $\begin{array}{l}\text { Whole attenuated } \\
\text { cold-adapted viruses }\end{array}$ & $\begin{array}{l}\text { Healthy } 5 \text { to } \\
49 \text {-year-olds }\end{array}$ & $\begin{array}{c}1 \text { or } 2 \\
\text { nasal doses }\end{array}$ & $0.5 \mathrm{~mL}$ \\
\hline
\end{tabular}

$\mathrm{HA}=$ hemagglutinin; $\mathrm{IM}=$ intramuscular; $\mathrm{NA}=$ neuraminidase.

* 6 months to 9 years: two doses during the first year of immunization. 
Table 2 - Influenza vaccines available in Brazil

\begin{tabular}{lcccc}
\hline Vaccine & Type of virus & Composition & Presentation & Laboratory \\
\hline Vaxigrip $^{\circledR}$ & Inactivated & $\begin{array}{c}\text { Split viruses } \\
(\mathrm{HA}, \mathrm{NA} \text { and capsule })\end{array}$ & $\begin{array}{c}\text { Multi-dose vial } \\
\text { Single dose syringes, } \\
\text { adult }(0.5 \mathrm{~mL}) \text { or } \\
\text { pediatric }(0.25 \mathrm{~mL})\end{array}$ & Sanofi-Pasteur \\
Fluarix ${ }^{\circledR}$ & Inactivated & $\begin{array}{c}\text { Split viruses } \\
(\mathrm{HA}, \mathrm{NA} \text { and capsule })\end{array}$ & $0.5 \mathrm{~mL}$ vial & GlaxoSmithKline \\
Inactivated flu vaccine & Inactivated & $\begin{array}{c}\text { Split viruses } \\
(\mathrm{HA}, \mathrm{NA} \text { and capsule })\end{array}$ & $0.5 \mathrm{~mL}$ vial & CSL \\
Inflexal ${ }^{\circledR}$ & Inactivated & $\begin{array}{c}\mathrm{HA} \text { and NA absorbed } \\
\text { into virosome particles }\end{array}$ & $0.5 \mathrm{~mL}$ vial & Berna \\
\hline
\end{tabular}

$\mathrm{HA}=$ hemagglutinin; $\mathrm{NA}=$ neuraminidase .

immunogenicity and safety to other vaccines. $47,48 \mathrm{~A}$ nasal formulation was used in a clinical trial with children and later abandoned due to a link with facial paralysis. 48,49

Recently, a trivalent, live, attenuated, cold-adapted influenza vaccine (LAIV) was licensed in the USA. ${ }^{50}$ An attenuated vaccine had been previously used in the nowextinct USSR and had been studied in the USA since the 1960s, being now revisited with nasal administration. 51,52 The vaccine that is currently licensed in the USA must be stored frozen at $-15^{\circ} \mathrm{C}$ and was approved for use with healthy children and adults from 5 to 49 years of age. 50 The attenuated influenza vaccine was shown to be safe, immunogenic and effective, although there are doubts about its safety in small children, the elderly and patients with immunosuppression, despite having been tested in clinical trials with these populations. ${ }^{53-55}$ This vaccine can induce systemic humoral and mucosal immunoresponse, in addition to cellular immunoresponse, being capable of inducing cross-protection against other influenza strains. 56 A liquid formulation that does not require freezing is currently in phase III clinical trials. 57

Influenza vaccines are modified annually, based on WHO recommendations. 1,58 Since 1947 , the WHO has coordinated epidemiological flu surveillance centers in many parts of the world, which today total 110 laboratories in 80 countries which systematically collect samples of respiratory secretions from patients with flulike disease. The influenza viruses isolated are then sent to global influenza surveillance centers, which are responsible for the complete identification of the viruses, with detailed antigenic descriptions. At the end of February every year, a group of WHO specialists meet to consider the epidemiological data collected during the previous year and to recommend which influenza strains will be most likely to cause epidemics the following year and should therefore be part of the vaccine to be used that winter in the Northern Hemisphere. The same procedure takes place at the end of September in Melbourne, Australia to define the composition of the Southern Hemisphere vaccine.

New approaches for producing influenza vaccines are being studied. 59 Some examples are the production of vaccines with cell cultures, vaccines using influenza genetic material, methods to increase the potency of current vaccines with the use of new adjuvants and new forms of administering the inactivated vaccines. Vaccines derived from cell cultures would not depend on fertilized eggs, which could lead to increased influenza vaccine production capacity. ${ }^{58-60}$

\section{Safety of the influenza vaccines in children}

The safety of trivalent inactivated and attenuated influenza vaccines has been tested in clinical trials and reviews of databases on vaccine-related adverse events.

Neuzil et al. ${ }^{7}$ reviewed adverse reactions at a clinical research center in the USA over a 5-year period (1985-90) in 277 children aged 1 to 16 years who were given 635 doses of vaccine. No severe reactions were observed and local reactions occurred in 6 to $14 \%$ of those who were vaccinated. In another randomized, double-blind, placebo controlled multicenter study of 2,032 patients with asthma, 712 of whom were aged 3 to 18 years, no asthma exacerbations were observed among those vaccinated up to 2 weeks after vaccination. 61

Guillian-Barré syndrome has not been linked with the inactivated vaccine in children, but the relatively small number of patients in the studies compromise their power for detecting extremely rare events. ${ }^{7}$ Ruben $^{8}$ revised all articles published on the inactivated influenza vaccine up to 2004, and described reactogenicity varying significantly between whole and split virus vaccines, with the latter 
being less reactogenic. The majority of reactions were local or febrile and varied significantly between studies.

Smith et al., 62 in a review published by the Cochrane Library, confirmed that local reactions and fever were the most common adverse events after influenza vaccination, whether with inactivated or attenuated vaccine. The authors emphasized the scant experience from clinical trials with inactivated vaccines in children less than 2 years old, although clinical experience is relevant.

Recently, McMahon et al. ${ }^{63}$ performed a 14-year review, 12 years ( 1990 to 2002 ) before and 2 years (2002-2003) after the recommendation for vaccinating children under 24 months, using data from the Centers for Disease Control and Prevention (CDC) Vaccine Adverse Event Report System (VAERS). The authors searched for reports of adverse reactions after vaccination with the inactivated influenza vaccine in children under 2 years old. They found reports of 166 events, 62 (37\%) of which were related to influenza vaccine alone and 104 (63\%) occurred after influenza vaccine was given together with other vaccines. Fever (59\%) was the most common event, followed by rash $(42 \%)$, convulsions ( $28 \%$ ) and local reactions (28\%). It is estimated that in 2002/2003, around 424,667 to 513,403 children were vaccinated, with 61 reports of adverse events, with a frequency of 0.014 to $0.012 \%$. Just 18 of these were associated with influenza vaccination alone, significantly reducing this rate to around 3:100,000 doses. These data are corroborated by information obtained from the São Paulo state health department, which also showed that reports of adverse events after influenza vaccination in children was not very representative (Sato $\mathrm{HK}$, personal communication at a meeting of the Department of Infectious Diseases of Sociedade de Pediatria de São Paulo, held in São Paulo, SP, on August 8, 2005).

Izurieta et al. ${ }^{64}$ used the CDC VAERS system to review reports of adverse events in children and adults receiving the attenuated influenza vaccine during the period after its licensure, from 2003 to 2005 . A total of 2.5 million people were vaccinated, with 460 adverse events reported, including seven reports of anaphylactic shock, two of Guillian-Barré syndrome, one of facial paralysis and eight asthma exacerbations. In $16 \%$ of the adverse event reports the vaccine had been given to patients for whom it was not indicated, i.e. healthy individuals aged 5 to 49 years. These data corroborate previous observations made in clinical trials that characterized the attenuated influenza vaccine as safe. ${ }^{52,55}$ In a clinical trial conducted by Piedra et al., 53 the attenuated vaccine demonstrated a satisfactory safety profile, including in the children under 5 years of age.

\section{Immunogenicity}

The immunogenicity of the inactivated influenza vaccine is directly proportional to age. ${ }^{7}$ In children under 6 years of age, approximately 40 to $80 \%$ exhibit seroconversion after a single dose of vaccine, while for children over 6 years the rate of seroconversion rises to 70 to $100 \% .65,66$ More than $50 \%$ of children under 3 years old and around $30 \%$ of children up to 9 years old are seronegative for the influenza virus. ${ }^{67}$ This fact results in the recommendation to give two doses of vaccine to the 6 months to 9 years age group the first year of vaccination, with just one dose being required annually thereafter. 68

Recently, Englund et al. ${ }^{69}$ studied the immunogenicity of the inactivated influenza vaccine in children from 6 to 23 months. These authors assessed the immunogenicity of the classic course of two doses with a 1 month interval and compared it with a course using a 6 month interval between doses, using vaccines with the same antigenic composition. Overall, rates of seroconversion were from 58 to $88 \%$, varying for each of the three antigens, and no differences were observed between the two vaccine courses. These results support the idea that the reduced response to the influenza vaccine in children is associated with the need for previous contact with the antigen and thus could favor the immunization of small children with doses left over from previous years with the second dose being given during the annual vaccination season.

The attenuated influenza vaccine exhibits seroconversion rates of 61 to $96 \%$ measured by hemagglutination inhibition titers that are elevated four times or more. 52 In another study the rates of seroconversion were 90,50 and $16 \%$, varying according to influenza subtype. ${ }^{70}$ In truth, there is no exclusive measure of seroconversion, since the vaccine also induces mucosal and cellular immunity. 50

\section{Efficacy of the influenza vaccine in children}

The results of clinical trials investigating the efficacy of the inactivated influenza vaccine vary greatly, depending on the primary objective of each study. ${ }^{8}$ In general, efficacy against confirmed influenza virus infection varies from 31 to $91 \%$ and is not uniform for the subtypes. Protective efficacy for acute otitis media (AMO) is more variable, being reported as absent by some authors and up to $36 \%$ by others.

Hurwitz et al. ${ }^{71}$ studied the inactivated influenza vaccine in 150 children from 2 to 5 years old who attended daycare. Protective efficacy against influenza infections, confirmed by serology, was $45 \%$ for influenza virus $B$ and $31 \%$ influenza virus $A$. Prevention of acute febrile flu-like disease was studied by Colombo et al. ${ }^{72}$ in 344 healthy children aged 1 to 6 years, in a randomized, controlled trial. The vaccinated group ( $n=177$ ) exhibited a $67 \%$ reduction in episodes of acute febrile disease when 
compared with the control group ( $n=167)$ (12.4 vs. $37.7 \%$, respectively).

In a review of clinical trials conducted from 1985 to 1990, Neuzil et al. ${ }^{73}$ studied the efficacy of the inactivated influenza vaccine in healthy children less than 16 years old. With the primary outcome of protection against influenza infections confirmed by culture, efficacy was 77 to $91 \%$ against the $\mathrm{A} / \mathrm{H} 3 \mathrm{~N} 2$ and $\mathrm{A} / \mathrm{H} 1 \mathrm{~N} 1$ influenza viruses, respectively.

Hoberman et al. ${ }^{74}$ studied the protective efficacy against $A M O$ of the inactivated influenza vaccine in children from 6 to 24 months who attended daycare during two flu seasons. The authors did not observe differences between the vaccinated group and a placebo group, but up to $66 \%$ protection from influenza infections was observed, confirmed by culture. Heikkinen et al. ${ }^{75}$ assessed children from 1 to 3 years of age with $n=187$ in each group, vaccinated and unvaccinated respectively, and observed a reduction of $36 \%$ in AMO episodes (34 vs. $53 \%$, vaccinated vs. unvaccinated). The same study reported protective efficacy against confirmed influenza $A$ infection of $83 \%$ ( 3 vs. $29 \%$, vaccinated and unvaccinated, respectively). Clements et al., ${ }^{76}$ in a retrospective study of 186 children from 6 to 30 months de age, reported reductions of $32 \%$ in AMO episodes.

Kramarz et al. ${ }^{77}$ reported efficacy in asthma patients for reducing asthma exacerbations after vaccination with the inactivated influenza vaccine. Sugaya et al. ${ }^{78}$ reported 67 and $44 \%$ protection against influenza $A$ and $B$, respectively, in asthmatic individuals.

A study of attenuated influenza vaccine carried out by Belshe et al. 52 found efficacy of 87 to $93 \%$ against confirmed infection by the influenza $A$ virus the first year of vaccination and 86 to $87 \%$ the second year, when the strain of influenza A virus in circulation was different from that present in the vaccine. The reduction in AMO was $27 \%$. Gaglani et al. ${ }^{79}$ observed reductions of 18 to $20 \%$ in the number of medical consultations for episodes of acute respiratory infections in children vaccinated with the attenuated influenza vaccine.

Jefferson et al. ${ }^{80}$ reviewed the efficacy of the attenuated vaccine in healthy children, reporting it at $79 \%$. These authors report that the efficacy of the inactivated vaccine is $65 \%$. The effectiveness of vaccination was $38 \%$ for the attenuated vaccine and $28 \%$ for the inactivated vaccine, in both cases for children older than 2 years. Efficacy for children younger than 2 years was not studied systematically, with the exception of the investigations into AMO episodes mentioned above.

Population-based studies of the impact of influenza vaccination with the inactivated vaccine in schoolchildren showed control of influenza epidemics with reductions in the total number of cases and in viral dissemination. 81 The same result was recently reported for the attenuated vaccine by Piedra et. al. ${ }^{82}$ who observed reductions in the number of medical consultations in unvaccinated people when vaccination coverage reached $25 \%$ of schoolchildren. In Japan, the national program for influenza vaccination of schoolchildren was associated with reduced mortality by influenza among the elderly. ${ }^{83}$ Universal influenza vaccination is currently under debate as a more effective alternative for preventing the disease. 68,84

\section{Final comments}

Acute respiratory infections are a worldwide public health problem, with significant impact on morbidity and mortality in children under 5 years of age and in other high-risk populations. ${ }^{31}$ Vaccination is an effective measure for controlling these diseases, as has been observed for measles and invasive Haemophilus influenzae type $B$ infections. ${ }^{85}$ Vaccination against influenza has surfaced as a new weapon in the fight to prevent ARI in children. With the epidemiological data that are currently available on the impact of this agent on the pediatric age group, we can infer that the benefits of vaccination would be reductions in morbidity, observed through the reductions in number of hospital admissions, medical consultations and antibiotic prescriptions for healthy children during influenza epidemics. 84

Without doubt, a major impact would be felt from an influenza immunization program that covered all schoolchildren, however, the vaccination of small groups, particularly through programs in partnership with businesses or health insurance plans, would be a good start for assessing the impact of influenza vaccination. 68,84 Secondary benefits, such as reductions in parents' absenteeism from work, reduced circulation of influenza viruses at daycare centers, and even reductions in secondary cases among family members would be another impact of vaccination against influenza in children, which would make vaccination more cost-effective.

Therefore, the current recommendation on influenza vaccination for children is that pediatricians should indicate the vaccination of all children over 6 months old with risk factors and for all children aged 6 to 23 months. For all other age groups, it is suggested that the vaccine be offered, emphasizing the benefits of vaccination for the prevention of influenza infections and their complications.

\section{Conflict of interest}

Otávio A. L. Cintra declares that he is a member of the speaker's bureau and works on research protocols for Sanofi-Pasteur do Brasil. He further declares that he is also a member of the speaker's bureau for GlaxoSmithKline do Brasil. 


\section{References}

1. Cintra $\mathrm{OAL}$, Arruda E. Influenza. In: Farhat CK, Carvalho ES, Weckx LY, Falleiros LHR, Succi RCM, editores. Fundamentos e prática das imunizações em clínica médica e pediatria. São Paulo: Atheneu; 2000. p. 450-91.

2. Centers for Disease Control and Prevention, Advisory Committee on Immunization Practices. Prevention and control of influenza. MMWR. 2005;54(RR08):1-40.

3. American Academy of Pediatrics, Committee on Infectious Diseases. Recommendations for influenza immunization of children. Pediatrics. 2004;113:1441-7.

4. American Academy of Pediatrics, Committee on Infectious Diseases. Reduction of the influenza burden in children. Pediatrics. 2002;110:1246-52.

5. Neuzil KM, Mellen BG, Wright PF, Mitchel EF Jr, Griffin MR. The effect of influenza on hospitalizations, outpatients visits, and courses of antibiotics in children. N Engl J Med. 2000;342:225-31.

6. Izurieta HS, Thompson WW, Kramarz P, Shay DK, Davis RL, DeStefano $F$, et al. Influenza and the rates of hospitalization for respiratory disease among infants and young children. N Engl J Med. 2000;342:232-9.

7. Neuzil KM, Edwards KM. Influenza vaccines in children. Semin Pediatr Infect Dis. 2002;13:174-81.

8. Ruben FL. Inactivated influenza virus vaccines in children. Clin Infect Dis. 2004;38:678-88.

9. Murphy BR, Webster RG. Orthomyxoviruses. In: Fields BN, Knipe DM, Howley PM, editors. Fundamental virology. 3rd ed. Philadelphia: Lippincot; 1996. p. 1397-445.

10. Beigel JH, Farrar J, Han AM, Hayden FG, Hyer R, de Jong MD, et al. Avian influenza A (H5N1) infection in humans. N Engl J Med. 2005;353:1374-85.

11. Webster RG. Wet markets - a continuing source of severe acute respiratory syndrome and influenza? Lancet. 2004;363:234-6.

12. Simonsen L, Fukuda K, Schonberger LB, Cox NJ. Impact of influenza epidemics on hospitalizations. J Infect Dis. 2000;181:831-7.

13. Thompson WW, Shay DK, Weintraub E, Brammer L, Cox N, Anderson LJ, et al. Mortality associated with influenza and respiratory syncytial virus in the United States. JAMA. 2003;289:179-86.

14. de Paiva TM, Ishida MA, Hanashiro KA, Scolaro RM, Gonçalves MG, Benega, MA, et al. Outbreak of influenza type A (H1N1) in Iporanga, São Paulo State, Brazil. Rev Inst Med Trop Sao Paulo. 2001;43:311-5.

15. Cintra OAL, Feitosa MAI, Paula FE, Silva ML, Cervi MC, Licio JE, et al. Impact of influenza (Flu) and respiratory syncytial virus (RSV) infections in pediatric hospitalizations in subtropical Brazil. In: XLIII Annual Meeting of Sociedad Latinoamericana de Investigación Pediátrica; 2005 Nov 6-10; Ribeirao Preto, Brazil. p.103. www.slaip.org.ar. Access: 18/04/2006.

16. Arruda E, Hayden FG. Influenza virus, respiratory syncytial, parainfluenza viruses, rhinovirus, and respiratory adenoviruses. In: Guerrant RL, Walker DH, Weller PF, editors. Tropical infectious diseases - principles, pathogens \& practice. Philadelphia: Churchill Livingstone; 1999. p. 1109-21.

17. Glezen WP, Couch RB. Interpandemic influenza in the Houston area, 1974-76. N Engl J Med. 1978;298:587-92.

18. Glezen WP, Keitel WA, Taber LH, Piedra PA, Clover RD, Couch RB. Age distribution of patients with medically-attended illnesses caused by sequential variants of influenza A/H1N1; comparison to age-specific infection rates, 1978-1979. Am J Epidemiol. 1991; 133:296-304.

19. Neuzil KM, Hohlbein C, Zhu Y. Illness among schoolchildren during influenza season: effect on school absenteeism, parenteral absenteeism from work, and secondary illness in families. Arch Pediatr Adolesc Med. 2002;156:986-91.

20. Neuzil KM, Zhu Y, Griffin MR, Edwards KM, Thompson JM, Tollefson SJ, et al. The burden of interpandemic influenza in children younger than 5 years: a 25 -year prospective study. J Infect Dis. 2002;185:147-52.

21. Principi N, Esposito S, Marchisio P, Gasparini R, Crovari P. Socioeconomic impact of influenza on healthy children and their families. Pediatr Infect Dis J. 2003;22(10 Suppl):S207-10.

22. Munoz FM. The impact of influenza in children. Semin Pediatr Infect Dis. 2002;13:72-8.

23. Sugaya N. Influenza-associated encephalopathy in Japan. Semin Pediatr Infect. Dis. 2002;13:79-84.
24. Maricich SM, Neul JL, Lotze TE, Cazacu AC, Uyeki TM, Demmler G], et al. Neurologic complications associated with influenza A in children during the 2003-2004 influenza season in Houston, Texas. Pediatrics. 2004;114:e626-33.

25. Centers for Disease Control and Prevention. Severe morbidity and mortality associated with influenza in children and young adults - Michigan, 2003. MMWR Morb Mortal Wkly Rep. 2003; 52:837-40.

26. Centers for Disease Control and Prevention. Update: influenza activity - United States, January 18-24, 2004. MMWR Morb Mortal Wkly Rep. 2004;53:63-5.

27. Glezen WP, Decker M, Joseph SW, Mercready RG Jr. Acute respiratory disease associated with influenza epidemics in Houston, 1981-1983. J Infect Dis. 1987;155:1119-26.

28. Glezen WP. Morbidity associated with the major respiratory viruses. Pediatr Ann. 1990;19:535-6.

29. Monto AS. Occurrence of respiratory virus: time, place and person. Pediatr Infect Dis J. 2004;23(1 Suppl):S58-64.

30. O'Brien MA, Uyeki TM, Shay DK, Thompson WW, Kleinman K, McAdam $A$, et al. Incidence of outpatient visits and hospitalizations related to influenza in infants and young children. Pediatrics. 2004; 113:585-93.

31. World Health Organization. The world health report 2005 - make every mother and child count. http://www.who.int/whr/2005/ annex/annexes3-4_en.pdf. Access: 18/04/2006.

32. Steinhoff MC. Viral vaccines for the prevention of childhood pneumonia in developing nations: priorities and prospects. Rev Infect Dis. 1991;13 Suppl 6:S562-70.

33. Kim PE, Musher DM, Glezen WP, Rodriguez-Barradas MC, Nahm WK, Wright CE. Association of invasive pneumococcal disease with season, atmospheric conditions, air pollution, and isolation of respiratory viruses. Clin Infect Dis. 1996;22:100-6.

34. Peltola VT, McCullers JA. Respiratory viruses predisposing to bacterial infections: role of neuraminidase. Pediatr Infect Dis J. 2004;23(1 Suppl):S87-97.

35. O’Brien KL, Walters MI, Sellman J, Quinslisk P, Regnery $H$, Schwartz B, et al. Severe pneumococcal pneumonia in previously healthy children: the role of preceding influenza infection. Clin Infect Dis. 2000;30:784-9.

36. Okamoto S, Kawabata S, Fujitaka H, Uehira T, Okuno Y, Hamada S. Vaccination with formalin-inactivated influenza vaccine protects mice against lethal influenza Streptococcus pyogenes superinfection. Vaccine. 2004;22:2887-93.

37. McCullers JA. Effect of antiviral treatment on the outcome of secondary bacterial pneumonia after influenza. J Infect Dis. 2004;190:519-26.

38. Cintra OA, Owa MA, Machado AA, Cervi MC, Figueiredo LT, Rocha GM, et al. Occurrence and severity of infections caused by subgroup $A$ and $B$ respiratory syncytial virus in children in southeast Brazil. J Med Virol. 2001;65:408-12.

39. Cintra OAL, Feitosa MAI, Paula FE, Silva KZ, Silva ML, Bueno $\mathrm{CDF}$, et al. Vírus influenza: características clínicas em crianças menores de 3 anos hospitalizadas por infecção respiratória aguda durante surto. J Paranaense Pediatr. 2005;6:56.

40. Tiraboschi AA, Bueno CDF, Cintra OAL, Cervi MC, Feitosa MAI, Silva ML, et al. Associação de pneumonia pneumocócica e surto de vírus influenza. J Paranaense de Pediatria. 2005;6:49.

41. Moura FEA, Borges LC, Souza LSF, Ribeiro DH, Siqueira MM, Ramos $E$, et al. Hospital study of acute respiratory infections in children of Northeast Brazil. J Bras Patol Med Lab. 2003;39: 275-82.

42. Souza LS, Ramos EA, Carvalho FM, Guedes VM, Souza LS, Rocha $\mathrm{CM}$, et al. Viral respiratory infections in young children attending day care in urban Northeast Brazil. Pediatr Pulmonol. 2003;35:184-91.

43. Sutmoller F, Nascimento JP, Chaves JR, Ferreira V, Pereira MS. Viral etiology of acute respiratory diseases in Rio de Janeiro: first two years of a longitudinal study. Bull World Health Organ. $1983 ; 61: 845-52$.

44. Nascimento JP, Siqueira MM, Sutmoller F, Krawczuk MM, de Farias V, Ferreira V, et al. Longitudinal study of acute respiratory diseases in Rio de Janeiro: occurrence of respiratory viruses during four consecutive years. Rev Inst Med Trop Sao Paulo. 1991;33:287-96.

45. Straliotto SM, Siqueira MM, Muller RL, Fischer GB, Cunha ML, Nestor SM. Viral etiology of acute respiratory infections among children in Porto Alegre, RS, Brazil. Rev Soc Bras Med Trop. 2002;35:283-91. 
46. de Arruda E, Hayden FG, McAuliffe JF, de Sousa MA, Mota SB, McAuliffe MI, et al. Acute respiratory viral infections in ambulatory children of urban northeast Brazil. J Infect Dis. 1991;164:252-8.

47. Huckriede A, Bungener L, Stegmann T, Daemen T, Medema J, Palache AM, et al. The virosome concept for influenza vaccines. Vaccine. 2005;23 Suppl 1:S26-38.

48. de Bruijn IA, Nauta J, Cramer WC, Gerez L, Palache AM. Clinical experience with inactivated, virosomal influenza vaccine. Vaccine. 2005;23 Suppl 1:S39-49.

49. Esposito S, Marchisio P, Cavagna R, Gironi S, Bosis S, Lambertini $L$, et al. Effectiveness of influenza vaccination of children with recurrent respiratory tract infections in reducing respiratoryrelated morbidity within the households. Vaccine. 2003;21: 3162-8.

50. Harper SA, Fukuda K, Cox NJ, Bridges CB; Advisory Committee on Immunization Practices. Using live, attenuated influenza vaccine for prevention and control of influenza: supplemental recommendations of the Advisory Committee on Immunization Practices (ACIP). MMWR Recomm Rep. 2003;52:1-8.

51. Khan AS, Polezhaev F, Vasiljeva R, Drinevsky V, Buffington J, Gary $H$, et al. Comparison of US inactivated split-virus and Russian live attenuated, cold-adapted trivalent influenza vaccines in Russian schoolchildren. J Infect Dis. 1996;173:453-6.

52. Belshe RB, Mendelman PM, Treanor J, King J, Gruber WC, Piedra $P$, et al. The efficacy of live attenuated, cold-adapted, trivalent, intranasal influenza virus vaccine in children. $\mathrm{N}$ Engl J Med. 1998;338:1405-12.

53. Piedra PA, Gaglani MJ, Riggs M, Herschler G, Fewlass C, Watts $M$, et al. Live attenuated influenza vaccine, trivalent, is safe in healthy children 18 months to 4 years, 5 to 9 years, and 10 to 18 years of age in a community-based, nonrandomized, openlabel trial. Pediatrics. 2005;116:e397-407.

54. King JC Jr, Fast PE, Zangwill KM, Weinberg GA, Wolff M, Yan L, et al Safety, vaccine virus shedding and immunogenicity of trivalent, cold-adapted, live attenuated influenza vaccine administered to human immunodeficiency virus-infected and noninfected children. Pediatr Infect Dis J. 2001;20:1124-31.

55. Bergen R, Black S, Shinefield H, Lewis E, Ray P, Hansen J, et al. Safety of cold-adapted live attenuated influenza vaccine in a large cohort of children and adolescents. Pediatr Infect Dis J. 2004;23:138-44.

56. Belshe RB, Gruber WC, Mendelman PM, Mehta HB, Mahmood K, Reisinger $\mathrm{K}$, et al. Correlates of immune protection induced by live, attenuated, cold-adapted, trivalent, intranasal influenza virus vaccine. J Infect Dis. 2000;181:1133-7.

57. Anonymous. Influenza virus vaccine live intranasal - MedImmune vaccines: CAIV-T, influenza vaccine live intranasal. Drugs $R$ D. 2003;4:312-9.

58. Gerdil C. The annual production cycle for influenza vaccine. Vaccine. 2003;21:1776-9.

59. Kemble G, Greenberg H. Novel generations of influenza vaccines. Vaccine. 2003;21:1789-95.

60. Bardiya $\mathrm{N}$, Bae JH. Influenza vaccines: recent advances in production technologies. Appl Microbiol Biotechnol. 2005;67: 299-305.

61. American Lung Association, Asthma Clinical Research Centers. The safety of inactivated influenza vaccine in adults and children with asthma. N Engl J Med. 2001;345:1529.

62. Smith S, Demicheli V, Di Pietrantonj C, Harnden A, Jefferson T, Matheson NJ, et al. Vaccines for preventing influenza in healthy children. Cochrane Database Syst Rev 2006;25:CD004879.

63. McMahon AW, Iskander J, Haber P, Chang S, Woo EJ, Miles B, et al. Adverse events after inactivated influenza vaccination among children less than 2 years of age: analysis of reports from the vaccine adverse event reporting system, 1990-2003. Pediatrics. 2005; 115:453-60.

64. Izurieta HS, Haber P, Wise RP, Iskander J, Pratt D, Mink C, et al. Adverse events reported following live, cold-adapted, intranasal influenza vaccine. JAMA. 2005;294:2720-5.

65. Clover RD, Crawford S, Glezen WP, Taber LH, Matson CC, Couch RB. Comparison of heterotypic protection against influenza A/ Taiwan/86 (H1N1) by attenuated and inactivated vaccines to $A$ / Chile/83-like viruses. J Infect Dis. 1991;163:300-4.

66. Gruber WC, Taber LH, Glezen WP, Clover RD, Abell TD, Demmler $\mathrm{RW}$, et al. Live attenuated and inactivated influenza vaccine in school-age children. Am J Dis Child. 1990;144:595-600.

67. Piedra PA, Glezen WP. Influenza in children: epidemiology, immunity and vaccines. Semin Pediatr Infect Dis. $1991 ; 2: 140-6$.
68. Greenberg HB, Piedra PA. Immunization against viral respiratory disease: a review. Pediatr Infect Dis J. 2004;23(11 Suppl): S254-61.

69. Englund JA, Walter EB, Fairchok MP, Monto AS, Neuzil KM. A comparison of 2 influenza vaccine schedules in 6- to 23-monthold children. Pediatrics. 2005;115:1039-47.

70. King JC Jr, Lagos R, Bernstein DI, Piedra PA, Kotloff K, Bryant $M$, et al. Safety and immunogenicity of low and high doses of trivalent live cold-adapted influenza vaccine administered intranasally as drops or spray to healthy children. J Infect Dis. 1998;177:1394-7.

71. Hurwitz ES, Haber M, Chang A, Shope T, Teo ST, Giesick JS, et al. Studies of the 1996-1997 inactivated influenza vaccine among children attending day care: immunologic response, protection against infection, and clinical effectiveness. J Infect Dis. $2000 ; 182: 1218-21$.

72. Colombo C, Argiolas L, La Vecchia C, Negri E, Meloni G, Meloni $T$. Influenza vaccine in healthy preschool children. Rev Epidemiol Sante Publique. 2001;49:157-62.

73. Neuzil KM, Dupont WD, Wright PF, Edwards KM. Efficacy of inactivated and cold-adapted vaccines against influenza A infection, 1985 to 1990: the pediatric experience. Pediatr Infect Dis J. $2001 ; 20: 733-40$.

74. Hoberman A, Greenberg DP, Paradise JL, Rockette HE, Lave JR, Kearney $\mathrm{DH}$, et al. Effectiveness of inactivated influenza vaccine in preventing acute otitis media in young children: a randomized controlled trial. JAMA. 2003;290:1608-16.

75. Heikkinen T, Ruuskanen $O$, Waris M, Ziegler T, Arola M, Halonen $P$. Influenza vaccination in the prevention of acute otitis media in children. Am J Dis Child. 1991;145:445-8.

76. Clements DA, Langdon $L$, Bland $C$, Walter $E$. Influenza $A$ vaccine decreases the incidence of otitis media in 6- to 30-month-old children in day care. Arch Pediatr Adolesc Med. 1995; 149:1113-7.

77. Kramarz P, DeStefano F, Gargiullo PM, Davis RL, Chen RT, Mullooly JP, et al. Influenza vaccination in children with asthma in health maintenance organizations. Vaccine. 2000;18:2288-94.

78. Sugaya N, Nerome K, Ishida M, Matsumoto M, Mitamura K, Nirasawa $M$, et al. Efficacy of inactivated vaccine in preventing antigenically drifted influenza type $A$ and well-matched type $B$. JAMA. 1994;272:1122-6.

79. Gaglani MJ, Piedra PA, Herschler GB, Griffith ME, Kozinetz CA, Riggs $M W$, et al. Direct and total effectiveness of the intranasal, live-attenuated, trivalent cold-adapted influenza virus vaccine against the 2000-2001 influenza $A(H 1 N 1)$ and $B$ epidemic in healthy children. Arch Pediatr Adolesc Med. 2004;158:65-73.

80. Jefferson T, Smith S, Demicheli V, Harnden A, Rivetti A, Di Pietrantonj $C$. Assessment of the efficacy and effectiveness of influenza vaccines in healthy children: systematic review. Lancet. 2005;365:773-80.

81. Monto AS, Davenport FM, Napier JA, Francis T Jr. Modification of an outbreak of influenza in Tecumseh, Michigan by vaccination of schoolchildren. J Infect Dis. 1970;122:16-25.

82. Piedra PA, Gaglani MJ, Kozinetz CA, Herschler G, Riggs $M$, Griffith $M$, et al. Herd immunity in adults against influenzarelated illnesses with use of the trivalent-live attenuated influenza vaccine (CAIV-T) in children. Vaccine. 2005;23:1540-8.

83. Reichert TA, Sugaya N, Fedson DS, Glezen WP, Simonsen L, Tashiro $M$. The Japanese experience with vaccinating schoolchildren against influenza. N Engl J Med. 2001;344:889-96.

84. Principi N, Esposito $S$. Are we ready for universal influenza vaccination in paediatrics? Lancet Infect Dis. 2004;4:75-83.

85. Farhat CK, Cintra OA, Tregnaghi MW. Vaccination and the respiratory tract - what should we know? J Pediatr (Rio J). 2002;78 Suppl 2:S195-204.

Correspondence:

Otávio A. L. Cintra

Rua Rui Barbosa, 1775

CEP 14015-120 - Ribeirão Preto, SP - Brazil

Tel.: +55 (16) 3602.2925, +55 (16) 3625.1535,

+55 (16) 3635.0576

Fax: +55 (16) 3633.3935

E-mail: oacintra@uol.com.br 